\title{
ECOLOGICAL MODERNISATION OF THE UKRAINIAN ECONOMY AS A PREREQUISITE FOR GREEN GROWTH
}

\section{Moroz V. V.}

\section{INTRODUCTION}

Recently, more and more international calls have been made for the need of the transition of national economies to the new concept of economic development and growth, commonly referred to as the "green" economy. The concept of a "green economy" is gaining increasing public resonance, and is being actively discussed by government officials, experts, politicians, and public figures.

In the expert environment, there is no longer any objection to the thesis that the continuation of economic development without a radical change in the current economic model will lead to increased environmental threats and will make sustainable development impossible. Against this background, government officials, economists, politicians, and business representatives should begin to look for new avenues of development that will ensure sustainable economic growth, environmental restoration, and high levels of well-being. Thus, the search for ways to transition to a "green" economy is an urgent task and should occur on the basis of scientific substantiation of measures of state policy to stimulate the development of a "green" economy in Ukraine.

Ecological modernization is the basis for green growth. Today, one of the priority tasks is to develop principles for managing green modernization and to select levers of influence on economic entities to implement the green growth model.

The Sustainable Development Strategy of Ukraine for the period up to 2020 determines the goals, directions, priorities of the country's development. The purpose of the reforms is to achieve European standards of living, to implement the principles of sustainable development of Ukraine's economy, which is an extremely important task of public administration to build a welfare society, increase the competitiveness of the economy and implement the European integration strategy. 
Generally, the green economy concept emphasizes all aspects of the sustainable development framework. The United Nations Environment Program (UNEP) defines the green economy concept as an economic paradigm that improves welfare, social equity, and environmental degradation. The economy concept will not replace the sustainable development framework. Sustainable development is the main goal in the long-run, whereas the green economy concept is the actions that should be taken in order to achieve sustainability.

Several requirements are needed to apply the green economy concept. At national level, government needs to change their fiscal policies, introduce several environmentally friendly regulation, and reform their subsidy policies (for instance from fossil fuel subsidy to renewable energy subsidy). Moreover, government should also increase the public investment on the selected "green" sectors (UNEP 2011).

It must be admitted that under globalization of environmental challenges there is a necessity for forming green economy fundamentals, i.e. system of economic activities related to the production, distribution and consumption of goods and services that would improve human welfare in the long-term without exposing future generations to significant environmental risks, resource and environmental scarcity. Therefore, the development of green economy doctrine in the context of establishing national strategy for sustainable development can be considered as a major landmark and basis of public policy, when Ukraine can both demonstrate its commitment to approaches of environmentally safe development within joint environmental and economic space, and clearly identify main trends of its sustainable development for the near future.

The main goal of green economy is to achieve sustainable development, which includes three aspects, namely economic, environmental, and social. But implementation of a green economy concept needs additional aspects, such as public supports, policy reforms, and regulation adjustment. Moreover, green economy can be implemented differently across countries or regions, depending on the strength and weaknesses of a country or region. World practice shows that the development of green economy takes the form of sectoral model. UNEP strategy in this field foresees a switch of some key economic sectors such as agriculture, heating and lighting of buildings, energy, fishery, forestry, industry, tourism, transport, waste management and 
water resources management to the green track. It is to be admitted that today there is no "universal" formula for implementing green growth strategies. The transition to green economy depends on a number of political and institutional conditions, the level of economic development and other factors.

\section{Theoretical approaches to identify the components of green economy concept}

The green economy is a pathway to sustainable development. It is based on an economic model that differs from traditional ones in that it takes due consideration of environmental and social externalities, and does not focus on GDP growth as the ultimate goal. Instead it focuses on resource efficiency and natural capital as the building blocks of the economy, recognising that environmental degradation undermines longterm economic growth and human development.

The concept of a green economy is related to ecological modernisation. Ecological modernisation refers to an environmental policy, related to the precautionary principle, and involves long-term structural change of the patterns of production and consumption (Andersen and Massa, 2000). One of the main assumptions of this perspective is that economic growth and a sustainable use of resources can be achieved simultaneously. However, growth and resource consumption can be interpreted in different ways, and the theoretical basis of the green economy can be interpreted through the subfields of environmental and ecological economics.

The EU vision entails multiple facets of the green economy:

- economic aspects: an economy that secures growth, building on resource efficiency and sustainable consumption and production patterns;

- environmental aspects: an economy that preserves the natural capital, invests in natural resources and mitigates climate change through low-carbon and resource efficient solutions;

- social aspects: an economy that improves human well-being, provides decent jobs, reduces inequalities and tackles poverty.

In the same vein, the European Environment Agency has formulated its own definition of the green economy, which puts a clear focus on resource efficiency and natural ecosystem health and resilience as the two main pillars of the green economy. It also acknowledges that any economic 
model that fails to provide decent jobs and earnings will not be politically or socially viable, and hence includes aspects of human well-being as a third pillar, focusing on social equity and fair burden-sharing.

It should be noted that some researchers are trying to contrast the concepts of "green" and "blue" economy. Thus, V. Khimynets ${ }^{1}$ thinks that "The green model of economy is too expensive and not adapted to modern economic realities. It is more romantic than practical because it requires significant financial costs that only developed countries are capable of." The researcher points out that $\ll . .$. it is time to move to a competitive blue economy" business model, which allows manufacturers to offer better products at lower prices, by introducing innovations that not only increase profits but also generate environmental benefits.

Thus, within the framework of this interpretation of the concepts of "green" and "blue" economy, we see a certain antagonism and mutually exclusive. It should be noted that the concept of "blue economy" was proposed by Professor Gunter Pauli, as part of a scientific study of the business models of the future, commissioned by the United Nations in 1994.

In our view, such antagonism between green and blue economies is not and should not be, since these concepts are more likely to complement each other and should be considered, alongside nanoeconomy, as components of the green economy model that demonstrate different levels of economic processes and phenomena (Fig. 1).

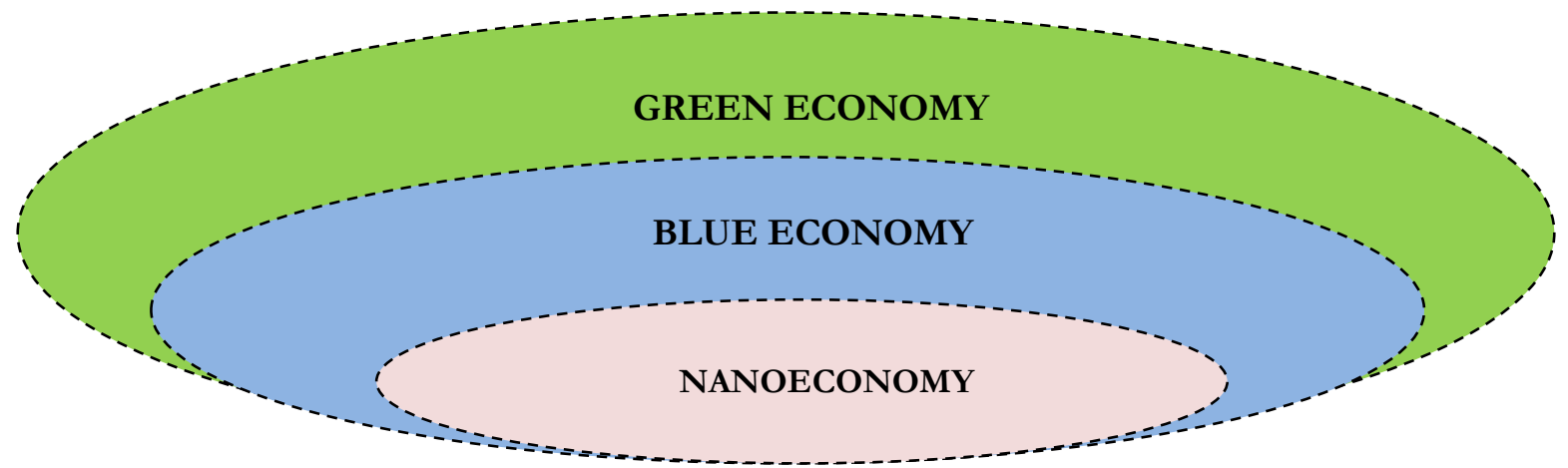

Fig. 1. Structuring the components of the green economy concept

The green economy component is formed at the level of state bodies, state environmental policy, and regional authorities, which is manifested

${ }^{1}$ Химинець В.В. Синя економіка - новий шлях до сталого розвитку. URL: http://www.confcontact.com/ 20130214_econ/8_himinets.htm 
through: state standardization and certification of production; creation of national and regional sovereign wealth funds; environmental taxes and fees (Tobin tax); state and regional environmental monitoring; national financial market for "green" securities; centralized budget expenditures for nature conservation; national and regional environmental programs; sectoral restructuring and modernization of production; the transition to new, environmentally-oriented technological structures.

The component of the "blue" economy is realized at the level of local self-government, municipalities and territorial communities, which is manifested through: entrepreneurship and entrepreneurial initiative; integrated use of local resources; public-private partnership; voluntary environmental certification and standardization; eco-oriented and resourcesaving technologies; social and environmental corporate responsibility; cluster-corporate mechanisms of environmental management; projects of sustainable development of territories and enterprises.

Nanoeconomy is formed at the level of individual economic agents, households operating through: small business, farming, personal subsidiary; environmental personality culture; environmental education and environmental thinking; saving natural resources in everyday life; separate collection of waste; resource- and energy-saving housing and appliances; "Smart home"; tariff and financial incentives for environmental resource consumption for the population; the interaction of technological structures, the systemic effect of the interaction of elements of technological structures with each other.

Thus, the concept of green economy has a major impact at the national and regional levels and involves an active environmental policy of the state and the regions, which in the person of the governing state bodies and regional authorities through the appropriate administrative, organizational, economic, legal, financial and other levers create the conditions for gradual economic growth based on economical and integrated use of natural resources, protection of the environment from harmful anthropogenic impacts and development of environmentally-friendly innovative industries and industries. Economic growth is not an end in itself, but a means. The state environmental policy of the green economy is aimed at the transition to new, less resource-intensive technological modes of production, comprehensive development of infrastructure, incl. environmental, etc. 
The EU is leading the "Greening Economies in the Eastern Neighbourhood" (EaP Green) project in six countries, including Ukraine, on behalf of a consortium of international organizations. The project is working at government and private sector levels (including SMEs) to: (i) mainstream sustainable consumption and production into national development plans, legislation and regulatory frameworks so that incentives are provided for development in line with policy commitments and good international practices, including those encouraged in the European Union; (ii) promote the use of strategic environmental assessment and environmental impact assessment as essential planning tools for environmentally sustainable economic development; and (iii) facilitate the greening of selected economic sectors (manufacturing, agriculture, food production and processing, construction).

Thus, generalizing these approaches, it is possible to form an integral definition of "green" economy as a new model of economic development. A green economy is a system of socio-economic relations that contributes to the conservation of the natural environment by improving resource efficiency, structural restructuring of the economy, the development of green sectors of the national economy and the reduction of brown, greening production and consumption. At the same time, the management system creates incentives for intensifying the investment processes in the "green" sectors of the economy and directs the overall "green" course of Ukraine.

\section{Green Economy as the main component of European Integration of Ukraine}

Attention to the green economy in EU policy has become prominent since 2011 in particular, through the communication 'Rio +20 : towards the green economy and better governance'(1), which presented the European Commission's approach to the green economy. It highlights the need to build an 'economy that can secure growth and development, while at the same time improving human well-being, providing decent jobs, reducing inequalities, tackling poverty and preserving the natural capital upon which we all depend' and stresses that 'moving towards a green economy necessitates preserving and investing in the assets of key natural resources ... It also means making use of low-carbon and resource efficient 
solutions and stepping up efforts to promote sustainable consumption and production patterns'

In the context of EU development cooperation, the Communication 'an Agenda for Change' (2) stated in 2011 that 'EU development policy should promote a 'green economy' that can generate growth, create jobs and help reduce poverty by valuing and investing in natural capital including through supporting market opportunities for cleaner technologies, energy and resource efficiency, low-carbon development while stimulating innovation, the use of information and communication technologies, and reducing unsustainable use of natural resources.

In line with EU development policy, the EU has been supporting actions contributing to the green economy for a number of years, including programmes in relevant areas, such as natural resources management, sustainable agriculture or renewable energies, and through the integration of environmental issues in relevant sectors, such as private sector development.

EU-funded initiatives in this category include for example the UN Partnership for Action on Green Economy (PAGE), the Green Economy Coalition (GEC) and the One Planet network, i.e. the network of the 10-year framework of programmes on SCP, a global action to 'enhance international cooperation to accelerate the shift towards sustainable consumption and production (SCP) in both developed and developing countries $^{2}$.

The EU's vision on the green economy implies that practices across many sectors of EU international cooperation contribute to the transition. This includes actions promoting green business practices in the context of private sector development; actions in environmental sectors, such as biodiversity and forestry; relevant agricultural practices that contribute to natural capital preservation; actions in the area of renewable energy production, energy efficiency and the fight against climate change; actions on sustainable cities; waste prevention (including re-manufacturing, repair, direct reuse) and management (waste collection, recycling, etc.); and actions in social sectors, notably initiatives to promote green and decent job creation

By signing the Association Agreement with the EU, Ukraine must meet a number of requirements relating to the environmental and

\footnotetext{
${ }^{2}$ UNEP. Green Economy Initiative. URL: http://www.unep.org/greeneconomy/
} 
environmental aspects of the agreement. Therefore, the development of a "green" economy in Ukraine becomes a prerequisite and an opportunity for our country's European integration.

The EU-Ukraine Association Agreement $^{3}$ requires adaptation of Ukraine's economy to European production standards and readiness for further prospects for integration into the European emissions trading market. For the past two decades, advanced European countries have been pursuing a greening economy that is built on the principles of sustainable development, thanks to a number of incentive mechanisms that are actively developing green sectors of the economy.

Given the direct and indirect threat of climate change, environmental pollution and inefficient use of natural resources, the European Union is actively supporting the creation of new climate policies by the six Eastern Partnership countries (Armenia, Azerbaijan, Belarus, Georgia, Moldova and Ukraine) based on countries' obligations under the Paris Climate Agreement, Association and Partnership Agreements with the EU. Accordingly, the scale of EU-Ukraine cooperation in the field of environmental protection and greening of our country's economy is outlined by the desire to minimize environmental externalities for the full existence of future generations.

The green economy includes activities that, in addition to improving production efficiency, contribute to improving the quality of life and, at the same time, significantly reducing the negative impact on the environment. The development of "green" sectors of the economy offer significant opportunities for investment, starting a profitable business, securing sustainable economic growth and job creation. First of all, we are talking about renewable energy sources, electricity, green building, waste processing and more. The green economy needs new approaches to regulation by national and regional public authorities, new business models, and specialist economists with relevant knowledge and skills. An important condition for greening the economy was the adoption of an appropriate regulatory framework harmonized with the Association Agreement with the European Union. In particular, in 2017-2019 Ukraine adopted the Low Carbon Development Strategy for 2050 (2018), the Energy Strategy for 2035 (2018), the Environmental Impact Assessment

3 Про Стратегію сталого розвитку «Україна - 2020» Президент України; Указ, Стратегія від 12.01.2015 № 5/2015 2. URL: http://zakon2.rada.gov.ua/laws/show/5/2015 
Act (2017), the Strategic Environmental Assessment Act, the Law principles (Strategy) of Ukraine's environmental policy for the period up to 2030 "(2019) and other environmental documents.

The analysis of the practice of application of these regulatory documents, the implementation plan of the EU-Ukraine Association Agreement on environmental issues shows that this area requires strengthening of the institutional capacity of both state authorities and local self-government, improvement of the legislative framework and adopted plans that form the basis of economy. in collaboration with the public sector and business.

Low-carbon development is the plan of Ukraine for the transition to a "green" economy, sustainable production, and consumption. The Government's priority is the large-scale reformation of outdated water carriage systems, the sphere of subsoil use, ensuring transparent and open business activities of these industries. For the first time since independence, the state policy in the sphere of waste management has been formed.

Many countries use different tools of the "green economy" in their national policies and development strategies. The Environmental policy in Ukraine is considering as an investment policy aimed at increasing of effectiveness of the use of natural resources through the development and use of new resourceefficient and energy-efficient low carbon technologies. Ukraine has only begun to change the course of the state environmental policy and environmental consciousness. The Government is getting used to looking at the whole spectrum of economic problems through the prism of ecology. The Government is supporting The National Waste Management Strategy until 2030 developed by the Ministry of ecology and natural resources of Ukraine. Together with international experts, the first package of legislative changes in the sphere of subsoil use has been developed, which would allow reforming and modernizing the subsoil extraction industry. The water management in Ukraine is being implemented on a watershed management principle, as it works around the world.

The implementation of the National Waste Management Strategy in Ukraine by 2030 requires the development of an additional set of legal norms to:

- create an effective government system for preventing environmental violationsand the state of the environment monitoring; 
- reduce pressure on the business community, wide involvement of the public in supervision (control);

- create a unified integrated state body of environmental monitoring and supervision (control) Services, developed on the concept of the system of government supervision (control) reforming in the field of environmental protection approved by the Ukraine's Cabinet of Ministers Decree from 05/31-2017, № 616-p.

Ukraine has substantial national resources, in particular land and minerals. The sustainable use of these resources requires the introduction of sustainable management practices with a people-centred approach. Environmental degradation, air pollution and toxic chemicals released into the environment has been contributing to a high NCD burden and other worsened health outcomes. Among occupational risks, asbestos is the most dangerous health threat.

The national policy should be based on the 10-Year Framework of the Programme on Sustainable Consumption and Production Patterns (Rio 2012), a global platform for capacity building and partnership on sustainable production and consumption. The provisions of the framework should be reflected in either the national strategy or the sectorial and regional development strategies. The framework provides for implementation of priority programmes: sustainable lifestyles and education, sustainable ('green') procurement, consumer information, sustainability in the construction and operation of facilities, sustainable food systems etc. To achieve this goal, it is necessary to create legal and institutional preconditions for the establishment of a green economy in Ukraine, which will significantly reduce the dependence of economic growth on the use of natural resources and energy.

Sustainable development of Ukraine must be comprehensive, which involves the modernization of industry, agriculture and other sectors of the national economy. It should also create conditions for the growth of the national science and innovation sector, which will help build a new resource efficient economy. The Ukraine's energy sector is one of the main polluters. Emissions of pollutants of energy complex enterprises account for about $40 \%$ of total emissions and for $58 \%$ of stationary sources of pollution. To meet the needs of economic growth, the approved energy strategy up to 2030 envisages extensive development of the energy industry. The energy sector will go through substantial reform to ensure it 
meets consumers' interests by setting the appropriate pricing mechanisms, connecting consumers to energy networks and offering transparent billing processes in accordance with the principles of the Third Energy Package. It is necessary to start implementing the strategy of green economy development with detailed elaboration of mechanisms and ways of stimulating priority directions. The greatest positive effect of the stimulus mechanisms can be obtained by the economy of Ukraine, provided they are optimally combined in the medium and long term. The effect of incentive mechanisms should be to change the structure of the national economy in terms of an increase in the green sectors of the economy compared to the brown ones.

The formation of a "green" economy is a modern trend of ensuring the economic security of the state in the conditions of globalization. Improving the environmental situation ceases to be a line of expenditure of the state budget, and becomes the very essence of the new economic system. Thus, the state is creating new economic conditions for doing business, which attract investment precisely in the development of new "green" industries and the ecological transformation of "greening" of economic activity.

\section{Green modernization as a priority of green growth in Ukraine}

According to the Report on Green Transformation in Ukraine, based on OECD Green Growth Indicators ${ }^{4}$ progress towards green growth is dependent on several preconditions: inclusion of green transformation goals in the country's key development priorities; full support of green growth principles by relevant agencies; and a consensus based on dialogue between the authorities, the business community and the public. Political decisions should be based on multiple trade-offs required to balance such competing goals as ensuring economic growth and maintaining profitability, addressing social issues and conserving the environment.

The greening of the economy in Ukraine is taking place in the context of continuing transition to a market-oriented business environment and related institutional changes. This is a lengthy and complicated process of transition from a society based on centralised decision-making, administrative pricing, low social standards and egalitarianism (none of which encourage rational use of cheap energy and primary resources) to a

\footnotetext{
${ }^{4}$ URL: http://www.green-economies-eap.org/resources/2016_GreenTransformation\%20in\%20Ukraine\% 20ENG.pdf
} 
society where market competition induces all enterprises to increase added value at a lesser cost in the context of higher labour and resource prices while motivating the population towards rational consumption and a more responsible behaviour. This complex transformation often means that such issues as clean environment and resource-saving are put on the back burner. For this reason, positive results in these areas may serve as an important indicator of progress in economic reforms in Ukraine.

According to the World Bank, the Ukrainian economy which is to a significant extent based on low value-added exports is largely inefficient and therefore, in terms of per capita GNI, the country belongs to the lowermiddle-income group (USD 7,810 at PPP in 2015). A high degree of fixed assets depreciation (83.5\% in 2014) and outdated technologies, especially in the mining and metallurgical sector, result in excess consumption of primary resources, materials and energy. As a result the energy intensity of Ukrainian economy (0.34 toe/1000 USD in 2013 , according to IEA estimates) is 1.5 times higher than the EU average ${ }^{5}$.

Today Ukraine is facing a number of serious problems caused by the escalating conflict in the eastern part of the country, the occupation of the Crimea and an ongoing economic crisis. Coupled with accumulated structural problems, in 2015 this lead to a 9.9\% slump in the GDP and a $13.4 \%$ decline in industrial production. At the backdrop of severe resource limitations and imminent external threat, the conversion of Ukraine's economic development model and structural transformation are becoming a matter of survival.

The signing in 2014 of the Ukraine-EU Association Agreement and the adoption of the 2014-2017 action plan for its implementation (in particular, the Economic and Sectoral Cooperation section), as well as the approval of plans for implementing EU directives and regulations related to energy, environment and technical guidelines are all geared towards Ukraine's transition to the European green development model.

The Ukraine-2020 Sustainable Development Strategy adopted in January 2015 sets forward ambitious goals in respect of economic reforms designed, among other things, to ensure sustainable economic development without depleting the environment, while the Action Plan for the implementation of the Ukraine-2020 Strategy proposes integrated solutions

\footnotetext{
5 UNIDO. Green Industry Initiative. United Nations Industrial Development Organisation. URL: http://www.rmido.oig/what-we-do/enviromnent/resource-efficient-and-low-carbon-industrial-

production/greenindustry/green-industry-initiative.html
} 
for reforming environmental management and monitoring systems. They include:

- gradual harmonisation of Ukrainian legislation with EU directives as required by the Association Agreement (Chapter 6 on Environment);

- introduction of environmental impact assessment procedures with regard to plans and programmes as required by Directives 2011/92/EC and 2001/42/EC;

- introduction of the ve-stage waste management hierarchy as required by Directive 2008/98/EC on waste and preparation of action plans in the area of waste management;

- increase in the share of utilisation of municipal solid waste and maximising reuse and recycling of such waste;

- introduction of the "polluter pays" principle and extended producer responsibility, in particular for packaging;

- reform of the system of pricing and tariff setting for energy and fuels, revision of mechanisms ensuring the balance of energy, phasing out of cross-subsidies;

- creation of a government support mechanism to promote energy efficiency measures in residential buildings and state-financed organisations.

In addition, the action plan of the Cabinet of Ministers for 2016 aimed at supporting the implementation of the Ukraine-2020 Sustainable Development Strategy and the Implementation Plan of the EU Association Agreement contains a comprehensive package of tasks geared towards the green transformation of Ukraine's economy.

These include energy performance improvements, energy market reforms, revision of subsidies for the population, improvement of housing and utility services, development of the renewable energy sector, carrying out of the thermo-modernisation programme for the population, creation of favourable conditions for small and medium-sized businesses, modernisation of the industrial complex and the system of support for agricultural producers. Reforms of environmental and taxation policies and the government procurement system should be aligned accordingly.

It is expected that the greening of the economy will promote:

- creation of less resource-intensive sectors of the economy, new markets and new jobs; 
- introduction of new energy efficient technologies and revitalisation of innovation activities;

- higher labour productivity and business competitiveness through the efficient use of energy and resources and waste minimisation.

Ukraine does have a potential for advancing green economic activities, primarily in the fields of renewable energy, energy performance and organic farming. For instance, in 2010-2014, the average annual growth in the bioenergy sector amounted to $42 \%$ while, according to the national renewable energy action plan up to 2020, the share of renewable energy in the gross final energy consumption is expected to reach $11 \%$ $(8,590$ toe $)$.

In line with the national energy efficiency action plan for the period up to 2020 , in 2020 final energy consumption should be $9 \%$ lower than the 2005-2009 annual average. The greatest savings in energy consumption are expected in the housing (50\% of the total volume) and industrial (25\%) sectors. To that end, a massive thermo-modernisation programme for residential buildings is currently underway and industrial enterprises are now more actively engaging in resource efficiency and cleaner production projects and introducing energy management systems (ISO 50001). On top of that, Ukraine has a great potential for organic farming. In 2014, the area used for growing organic crops reached 400.8 ha, the number of certified organic producers grew to 182 and the sales of organic produce were estimated at EUR $14.5 \mathrm{mln}$.

Recently, the survey of business companies titled Business and 'Green' Modernisation of Economy: Opportunities and Barriers was held under the Programme to Support the Green Modernisation of the Ukrainian Economy financed by the German Government and implemented by the Deutsche Gesellschaft für Internationale Zusammenarbeit (GIZ) in the partnership with the Center for CSR Development and Ukrainian Chamber of Commerce and Industry ${ }^{6}$. The purpose of this survey was to identify key opportunities for and barriers to ecologisation of Ukrainian businesses.

The results of the survey showed that the following elements of 'green' modernisation are the most commonplace among Ukrainian companies:

- improved energy efficiency (installing new or upgrading existing equipment);

\footnotetext{
${ }^{6}$ URL: http://csr-ua.info/csr-ukraine/wp-content/uploads/2016/06/Analysis-Questionnaire-CSR.pdf
} 
- improved resource efficiency (minimisation of waste and rational use of water);

- 'green office' programmes;

- implemented environmental management system (mostly ISO 14001-compliant).

The key factor behind the implementation of 'green' modernisation is the attempt to improve one's competitive advantages and opportunities. Rising energy and raw material prices also played a substantial role in this.

The key advantages for companies implementing 'green' modernisation include cost and resource saving and increasing competitiveness.

Ukrainian companies have poor knowledge of 'green' modernisation and receive no consultations on these matters. Therefore, the lack of information regarding green technologies and the high cost and inaccessibility of these technologies are the main barriers hampering implementation of 'green' modernisation.

The main barriers to implementation of the key elements of 'green' modernisation are mostly internal factors, such as:

- lack of understanding of why 'green' modernisation is needed;

- low environmental awareness of personnel;

- technological specifics;

- limited financial resources.

The desire to improve one's competitive advantages and opportunities provides the impetus for Ukrainian companies to implement 'green' modernisation. Rising energy and raw material prices also played a substantial role in this. That was the factor that drove all surveyed companies to implement energy efficiency and resource efficiency improvement projects. Therefore, cost and resource saving and increasing competitiveness are the advantages which companies implementing 'green' modernisation gain.

The biggest barrier obstructing implementation of 'green' modernisation is, according to respondents, the lack of information regarding green technologies and the high cost and inaccessibility of these technologies. Another serious barrier is the complexity of administrative procedures and obsolete law. Most of the surveyed companies admitted that they do not possess sufficient knowledge of 'green' modernisation of economy and do not receive consultations on these matters; some of them said that they don't know who provides these consultations. The 
companies that do receive consultations seek them from civil and international organisations, business associations, banking institutions and own environmental management services.

Most companies in Ukraine now are trying to implement energy efficiency and resource efficiency improvement projects. Energy efficiency is being implemented mostly by installing new or upgrading existing equipment, while resource efficiency is being achieved by minimising waste and saving water.

Also many companies implement an ISO 14001-compliant environmental management system, corporate standards on environmental management, 'green office' programmes. The company's reputation and improvement of competitive advantages are the key factors prompting companies to implement environmental management system.

Few companies in Ukraine have experience in receiving reducedinterest financing or investing in 'green' modernisation. These benefits are provided by the European Bank for Reconstruction and Development. The same with implementation of eco-labeling of own products or uses alternative and renewable sources of energy

The survey ${ }^{7}$ showed that almost all companies experienced obstacles or difficulties when procuring special (ecological) licenses or implementing particular elements of 'green' modernisation. In most cases, they were related to subjective factors, such as lack of understanding why 'green' modernisation is needed or low environmental awareness of personnel. Technological specifics and limited financial resources available to a company played a substantial role, too. In the opinion of respondents, the main ways of overcoming these difficulties are internal processes of substantiating the need in 'green' modernisation, effectiveness of this measure and implementation of new engineering projects. The main obstacles to the procurement of special permits to use resources, waste disposal and air pollution permits are loopholes in regulatory framework of authorisation system and excessive bureaucracy of public license issuance system.

That is why the following steps should be taken to improve the situation.

Promoting dissemination of knowledge regarding 'green' modernisation of economy:

\footnotetext{
7 Main results of the survey "Improvement of small and medium-size business environmental performance". Research \& Branding Group, 2015, 49 p.
} 
- Implementing public information campaigns promoting advantages and effect of key elements of 'green' modernisation on business development, including under auspices of business associations.

- Devising educational courses on 'green' modernisation of economy for college and university students, especially students of technical universities.

- Organising national and regional contests on implementation of green economy projects.

- Preparing, based on the Contest's results, and disseminating collections of the best 'green' modernisation practices of international and Ukrainian companies (including in various sectors of economy), with calculations of effectiveness.

Implementing programs that stimulate implementation of key elements of 'green' modernisation:

- Promoting a dialogue between the government and businesses on stimulation of 'green' modernisation of economy, including improvement of regulatory framework (e.g. in waste management sphere).

- Preparing and submitting amendments to the existing legislation that introduce 'green' procurements.

- Introducing financial and tax benefits for companies implementing key elements of 'green' modernisation.

- Developing the potential of organisations offering consultations on 'green' modernisation of economy:

- Creating a database of consultants and organisations offering consultations on 'green' modernisation of economy.

- Organising regular meetings between companies and consultants under the auspices of business associations to establish contacts and partnerships.

\section{CONCLUSIONS}

Therefore, the development of a "green" economy in Ukraine requires active support from the state through the use of a number of incentive mechanisms: regulatory, organizational, economic, information, communication, budget and tax. The signing of the Association Agreement with the European Union is a good and effective impetus to greening the Ukrainian economy, developing and supporting new "green" sectors of the economy with a further prospect of transition to a "green" economy. 
Therefore, the following conclusions can be drawn from the analysis of approaches to defining the essence of a green economy.

1. The green economy is viewed by the world community as one of the ways of overcoming global and local problems of humanity, which offers real mechanisms for changing the modern economic model. It is one of the important tools for sustainable development that promotes people's well-being, economic growth and social justice while reducing the risks to the environment and the rational use of natural resources. Issues that arise in the process of implementing the concept of a green economy need comprehensive research to provide scientific support for the development of incentive mechanisms at the international, regional and local levels.

2. The concept of a green economy is widely promoted at the international and European levels, but unfortunately, it is not yet legally recognized in Ukraine. The development of legal support for shaping the foundations of a green economy should be one of the priority tasks of the state.

3. The implementation of a course on building a "green" economy in Ukraine through the implementation of appropriate state policy will contribute to the achievement of European standards of living, the introduction of sustainable development of the economy of Ukraine, which is extremely important task of public administration to build a welfare society, increase competitiveness and competitiveness strategies for why further research should be devoted.

Ukraine has to foster the integration of environmental sustainability principles into successful SME business activities. In some cases, this means that an existing SME may adopt a "green strategy" incorporating new environmental sustainability goals and actions into its business actions. In other cases, it means that new enterprises may be started that specifically target the provision of a "green" product or service.

Green business has developed in response to the growth of awareness about the environment, and the impacts of industry and consumers on the environment:

- Governments have established environmental norms and standards, and SMEs have developed to provide green services and products to enable these norms and standards to be met.

- Individuals have become increasingly aware of how their lifestyle and consumer choices impact the environment, and are demanding green 
products and services that minimize environmental impacts. SMEs are among the suppliers of green goods and services that respond to consumer demand.

Thus, at the present stage, the basis for successful development of Ukraine is the implementation of state policy aimed at economic recovery in accordance with the latest global trends of sustainable development, namely - to the model of "green economy".

\section{SUMMARY}

This paper deals with the origins of the green economy concept, providing the context for its current traction globally. The idea of green economy declared by UNEP in 2009 in its "Global Green New Deal" report is winning ever greater public attention. Its essence as the dominant paradigm at the present stage of social development is the ability to use the available free goods more effectively on the principles of inter-regional cooperation and mutual compensation of damages. The essence and factors of formation of the Green economy are discovered. The opportunities and prospects of Ukraine relative to Green Economy as a new paradigm of economic growth are defined. The obstacles to attraction of Ukraine into the European movement of greening of social activities are detected. The Government can help small and medium-sized enterprises to change their business practices and adapt to modern requirements, by "greening" the current strategy in the industry and innovation, promoting the concept of eco-efficient businesses and products and supporting the environmental innovation.

\section{REFERENCES}

1. Про Стратегію сталого розвитку «Україна - 2020» Президент України; Указ, Стратегія від 12.01.2015 № 5/2015 2. URL: http://zakon2.rada.gov.ua/laws/show/5/2015

2. Потапенко В.Г. Стратегічні пріоритети безпечного розвитку України на засадах «зеленої економіки» : монографія [за наук. ред. д.е.н., проф. Є.В. Хлобистова]. Київ : НІСД, 2012. 360 с.

3. Химинець В.В. Синя економіка - новий шлях до сталого розвитку. URL: http://www.confcontact.com/20130214_econ/8_himinets.htm 
4. OECD "Towards Green Growth: Monitoring Progress - OECD Indicators", OECD, Paris. URL: http://www.oecd.org/greengrowth/ 48224574.pdf

5. UNEP. Green Economy Initiative. URL: http://www.unep.org/ greeneconomy/

6. UNIDO. Green Industry Initiative. United Nations Industrial Development Organisation. URL: http://www.rmido.oig/what-wedo/enviromnent/resource-efficient-and-low-carbon-industrialproduction/greenindustry/green-industry-initiative.html

7. Main results of the survey "Improvement of small and medium-size business environmental performance". Research \& Branding Group, 2015, $49 \mathrm{p}$.

\section{Information about the author:}

Moroz V. V.

$\mathrm{PhD}$ in Public Administration, Associate Professor at the Economic Policy and Governance Department of the National Academy of Public Administration under the President of Ukraine 